\title{
Studi Evaluasi Sebaran Titik Panas (Hotspot) Sebagai Penduga Kebakaran Hutan Dan Lahan di Kabupaten Sintang
}

\author{
Ria Rosdiana Hutagaol \\ Fakultas Pertanian Universitas Kapuas Sintang \\ Email : riarose.h@gmail.com
}

\begin{abstract}
Abstrak : Penelitian ini bertujuan untuk mengetahui sebaran hotspot yang terdapat di wilayah Kabupaten Sintang tahun 2013 dan 2014 sebagai penduga terjadinya kebakaran hutan dan lahan serta untuk mengkaji penyebab terdapatnya hotspot tahun 2013 dan 2014 sebagai penduga terjadinya kebakaran hutan dan lahan di wilayah Kabupaten Sintang. Penelitian ini merupakan penelitian deskriptif kualitatif dengan teknik pengumpulan data melalui metode survey dan wawancara. Data titik panas atau hotspot tahun 2013 dan 2014 dari pemantauan satelit NOAA berupa titik koordinat ditumpangsusunkan (overlay) ke peta melalui Software Arc Gis. Hasil penelitian menunjukkan bahwa jumlah titik panas di Kabupaten Sintang Tahun 2013 dan Tahun 2014 adalah 1032 titik dengan sebaran titik panas terbanyak terdapat di Kecamatan Ketungau Hilir yaitu 205 titik. Sebaran titik panas terbanyak yang terdapat pada status Kawasan Hutan Di Kabupaten Sintang Tahun 2013 dan tahun 2014 adalah pada Areal Penggunaan Lain (APL) yaitu 770 titik.
\end{abstract}

Kata Kunci : Titik Panas, Kebakaran Hutan dan Lahan

\section{PENDAHULUAN}

Kebakaran hutan menjadi perhatian internasional sebagai isu lingkungan dan ekonomi, khususnya setelah bencana El Nino pada tahun 1997/98 yang menghanguskan lahan hutan seluas 25 juta hektar di seluruh dunia. Pencemaran kabut asap merupakan masalah berulang bahkan selama bertahun-tahun ketika peristiwa El Nino di Indonesia dan negaranegara tetangga tidak terjadi. Selama peristiwa El Nino 1997/98, Indonesia mengalami kebakaran hutan yang paling hebat di dunia. Masalah yang sama terulang pada 2002 (Tacconi,
2003). Saharjo (1999) menyatakan bahwa sebagian besar $(99,9 \%)$ kebakaran terjadi karena pembakaran yang sengaja dilakukan maupun akibat kelalaian, baik oleh peladang berpindah ataupun oleh pelaku bisnis kehutanan atau perkebunan, sedangkan sisanya $(0,1 \%)$ adalah karena alam (petir, larva gunung berapi).

Melihat besarnya dampak yang ditimbulkan oleh kejadian kebakaran hutan maka perlu dilakukan usaha pengendalian secara terus-menerus. Upaya pengendalian ini meliputi kegiatan pencegahan (Prevention) yang dilakukan sebelum kebakaran terjadi 
dan kegiatan pemadaman (Supression) yang dilakukan setelah terjadi kebakaran. Salah satu kegiatan pencegahan kebakaran hutan adalah melalui Early Detection System (Sistem Deteksi Dini) dengan menggunakan data hotspot. Hotspot merupakan titik panas yang dapat dimonitor oleh satelit National Oceanic and Atmospheric Administration (NOAA) yang dilengkapi dengan sensor Advance Very High Resolution Radiometer (AVHRR) untuk suhu $37^{\circ} \mathrm{C}$ dan $42^{\circ} \mathrm{C}$, pada hotspot bisa terdapat titik api dengan suhu $350^{\circ} \mathrm{C}$. Pemantauan hotspot dengan menggunakan satelit sangat tergantung pada penutupan awan, sehingga tidak semua hotspot terpantau oleh satelit. Dengan adanya hotspot maka pengendalian kebakaran hutan dan lahan di lapangan dapat segera dilakukan (Arief, 1997 dalam Thoha, 2008).

\section{METODE PENELITIAN}

Penelitian ini merupakan penelitian deskriptif kualitatif dengan teknik pengumpulan data melalui metode survey dan wawancara. Survey dilakukan ke Kantor Dinas Kehutanan dan Perkebunan Kabupaten Sintang untuk mendapatkan data hotspot tahun
2013 dan 2014 dari pemantauan satelit NOAA berupa titik koordinat yang ditumpangsusunkan (overlay) ke peta melalui Software Arc Gis. Hasil dari survey akan dievaluasi untuk menentukan lokasi pengamatan langsung (Observasi) dan wawancara terhadap orang yang memiliki hak penguasaan tanah atau pengguna lahan ditempat terdapatnya hotspot sebagai penduga terjadinya kebakaran hutan dan lahan.

Data primer dan data sekunder yang telah dikumpulkan, kemudian dianalisis dengan dilakukan pemilahan dan penyederhanaan. Pemilahan data dimaksudkan untuk mempertajam analisis. Setelah data dipilah selanjutnya dikelompokkan menjadi bagian-bagian yang saling berkaitan. Selanjutnya data disajikan dalam bentuk teks naratif atau dideskripsikan. Dari hasil penyajian dapat ditarik berbagai kesimpulan. Analisis dilakukan untuk menemukan sebaran hotspot melalui data hotspot tahun 2013 dan 2014 berupa titik koordinat yang ditumpangsusunkan (overlay) ke peta administratif Kota Sintang melalui Software Arc Gis. Sedangkan hasil wawancara dan pengamatan lapangan dilakukan dengan teknis Analisis Deskriptif yang 
memberikan gambaran yang jelas dan benar tentang penyebab terdapatnya hotspot tahun 2013 dan 2014.

\section{HASIL DAN PEMBAHASAN}

\section{Sebaran Titik Panas (Hotspot)}

\section{Bulanan Di Kabupaten Sintang}

\section{Tahun 2013}

Berdasarkan data dari Dinas

Kehutanan dan Perkebunan (Dishutbun)

Kabupaten Sintang, titik panas bulanan yang terdapat di Kabupaten Sintang dari bulan Mei sampai dengan Desember 2013 sebanyak 411 titik. Titik panas dipantau oleh Dishutbun Kabupaten Sintang dimulai pada bulan Mei 2013 dengan jumlah 2 titik. Titik panas terdeteksi mengalami peningkatan pada bulan Juni sebanyak 17 titik, bulan Juli 20 titik, bulan Agustus 140 titik dan puncaknya pada bulan September 176 titik. Penurunan jumlah titik panas terjadi pada bulan Oktober sebanyak 50 titik dan berlanjut menyisakan masingmasing 3 titik di bulan Oktober dan Desember.

Penyebaran titik panas yang terdapat pada setiap kecamatan di Kabupaten Sintang tahun 2013 secara berurutan adalah ; Ketungau Hilir 87 titik, Ketungau Tengah 84, Ketungau hulu 44 titik, Sepauk 31 titik, Tempunak
30 titik, Kayan Hilir 30 titik, Kelam Permai 23 titik, Dedai 16 titik, Binjai 16 titik, Ambalau 14 titik, Kayan Hulu 13 titik, Sungai Tebelian 11 titik, Sintang 8 titik dan Serawai 4 titik.

\section{Sebaran Titik Panas (Hotspot) Bulanan Di Kabupaten Sintang Tahun 2014}

Titik panas bulanan pada tahun 2014 di Kabupaten Sintang sebanyak 621 titik, yang terdeteksi dari bulan Januari 24 titik, Februari 22 titik, Maret 24 titik, April 20 titik, Mei 13 titik dan Juni 13 titik. Peningkatan titik panas secara signifikan terjadi pada bulan Juli sebanyak 197 titik, Agustus 156 titik dan September 136 titik. Sedangkan pada bulan Oktober titik panas mengalami penurunan yaitu 8 titik, November 5 titik dan Desember 6 titik.

Penyebaran titik panas yang terdapat pada setiap kecamatan di Kabupaten Sintang tahun 2014 secara berurutan adalah ; Ketungau Hilir 118 titik, Ketungau Hulu 79 titik, Tempunak 69 titik, Ketungau Tengah 63 titik, Kayan Hilir 48 titik, Sepauk 44 titik, Binjai 42 titik, Sungai Tebelian 38 titik, Kelam Permai 33 titik, Sintang 23 titik, Ambalau 22 titik, Dedai 18 titik, 
Serawai 13 titik dan Kayan Hulu 11 titik.

\section{Sebaran Titik Panas (Hotspot)} Pada Status Kawasan Hutan Di Kabupaten Sintang Tahun 2013 dan 2014

Penyebaran titik panas paling banyak terdapat pada status Kawasan Hutan Di Kabupaten Sintang Tahun 2013 secara berurutan adalah ; Areal Penggunaan Lain (APL) 286 titik, Hutan Produksi Terbatas (HPT) 62, Hutan Produksi (HP) 40, Hutan Lindung (HL) 19 dan Hutan Produksi Konservasi (HPK), Taman Nasional (TN) dan Taman Wisata Alam (TWA) 4 titik.

Penyebaran titik panas paling banyak terdapat pada status Kawasan Hutan Di Kabupaten Sintang Tahun 2014 secara berurutan adalah ; Areal Penggunaan Lain (APL) 484 titik, Hutan Produksi (HP) 58, Hutan Produksi Terbatas (HPT) 51, Hutan Lindung (HL) 22 dan Hutan Produksi Konservasi (HPK), Taman Nasional (TN) dan Taman Wisata Alam (TWA) 6 titik.

Berdasarkan data diatas menunjukan bahwa titik panas Tahun 2013 dan tahun 2014 paling banyak atau mengalami peningkatan yang sangat signifikan terjadi di bulan Juli, Agustus dan September. Titik panas tersebut tersebar diseluruh Kecamatan yang ada di kabupaten Sintang. Kecamatan Ketungau Hilir merupakan daerah yang paling banyak terdapat titik panas, yaitu 205 titik. Sedangkan yang paling banyak berdasarkan status Kawasan Hutan adalah Areal Penggunaan Lain (APL) sebanyak 770 titik.

Berdasarkan hasil wawancara dengan sebagian besar masyarakat yang mempunyai hak penguasaan tanah atau pengguna lahan ditempat terdapatnya hotspot pada beberapa kecamatan di Kabupaten Sintang, bahwa pada bulan Juli, Agustus dan September merupakan saatnya masyarakat melakukan aktivitas pembukaan lahan untuk berladang dengan cara membakar. Kecamatan Ketungau Hilir merupakan daerah yang paling banyak terdapat titik panas, hal ini dapat dimaklumi karena memang sebagian besar masyarakat bermata pencaharian sebagai petani dengan sistem berladang pindah yang melakukan aktivitas pembukaan lahan dengan cara dibakar.

Areal yang digunakan oleh masyarakat sebagai tempat untuk berladang adalah Areal Penggunaan 
Lain (APL) yang berdasarkan status Kawasan Hutan melalui Kepmenhut No. 963/Menhut-II/ 013 tentang Perubahan Peruntukan Kawasan Hutan, Perubahan Fungsi Kawasan Hutan dan Penunjukan Kawasan Hutan. Seperti diketahui bahwa APL merupakan kawasan yang diperuntukan sebagai hak milik masyarakat dan dapat digunakan untuk Izin Usaha Perkebunan. Dengan demikian sangatlah memungkinkan bahwa hotspot yang banyak terjadi pada bulan Juli, Agustus dan September karena aktivitas perladangan berpindah yang dilakukan oleh masyarakat dengan cara membakar di wilayah APL. Menurut Putra (2002), penyebab kebakaran hutan dan lahan di Kalimantan Barat $80 \%$ terjadi karena kegiatan pembersihan lahan saat musim kemarau dengan pembakaran yang mengakibatkan api merembet ke kawasan lain. Sebagian masyarakat masih menggunakan cara tradisional saat membersihkan lahan dengan membakar kawasan hutan atau areal pertanian.

Menurut keterangan dari Dinas Kehutanan dan Perkebunan Kabupaten Sintang, kebakaran pernah terjadi pada tanggal 7 Mei 2014 di batas wilayah administrasi antara Desa Buntut Pimpin dengan Desa Keremue Kecamatan Ambalau seluas \pm 5 hektar yang menjalar sampai ke Hutan Lindung dan Hutan Produksi Terbatas. Kebakaran disebabkan oleh aktivitas pembakaran lahan oleh masyarakat setempat. Pembakaran lahan oleh masyarakat juga pernah menyebabkan api merembet ketempat lainnya. Menurut keterangan dari Ketua Adat Desa Sungai Seria dan pihak perusahaaan PT. Palmindo Lestari, pada tanggal 19 Juli 2014 telah terjadi kebakaran seluas \pm 100 hektar di wilayah kerja PT. Palmindo Lestari dan PT. Inma Jaya di Desa Sungai Seria Kecamatan Ketungau Hilir. Api diketahui berasal dari pembakaran lahan milik masyarakat Dusun Pedian Desa Sungai Seria.

Pada tanggal 15 September 2014, kebakaran juga terjadi di Areal Izin Usaha Perkebunan Kelapa Sawit milik PT. Duta Rendra Mulya (DRM) di Desa Setungkup Kecamatan Ketungau Hilir. Menurut pihak perusahaan, bahwa pada tanggal 15 September 2014 terdapat masyarakat membakar ladang di lahan inclave berdekatan dengan blok E-4, setelah ditinggalkan ternyata masih terdapat bara api dan hidup kembali membakar pohon yang ada di ladang tersebut. Pada tanggal 16 September 
2014 sekitar pukul 15.00 wiba datang angin yang bertiup kencang dan membawa bara api dari pohon yang terbakar tersebut jatuh ke arah tumpukan blok E-3 sehingga menyebabkan kebakaran seluas \pm $178,30 \mathrm{Ha}$ yang terdiri dari $141,25 \mathrm{Ha}$ sudah tertanam dan 37,05 Ha belum tertanam.

Menurut Anderson, et,al. (1999), pada awalnya hotspot diidentikkan dengan titik api, namun dalam kenyataannya tidak semua hotspot mengindikasikan adanya titik api. Istilah hotspot lebih tepat bila bersinonimkan dengan titik panas. Sebuah titik panas merupakan satu pixel pada potret satelit adalah suatu areal 1.1 $\mathrm{km} 2$, dimana tinggi temperatur permukaannya mengindikasikan adanya kebakaran. Dalam konteks kebakaran hutan, hotspot adalah indikator kebakaran hutan yang mendeteksi suatu lokasi yang memiliki suhu relatif lebih tinggi dibandingkan dengan suhu disekitarnya (Peraturan Menteri Kehutanan Nomor P.12/Menhut-II/2009 tentang Pengendalian Kebakaran Hutan).

\section{KESIMPULAN}

1. Total titik panas di Kabupaten Sintang Tahun 2013 dan Tahun 2014 terdapat 1032 titik. Jumlah titik panas tersebut tersebar pada bulan Januari 24 titik, Februari 22 titik, Maret 24 titik, April 20 titik, Mei 15 titik dan Juni 27 titik. Peningkatan terjadi sejak bulan Juli 217 titik, Agustus 296 titik dan September 312 titik. Penurunan titik panas terjadi sejak bulan Oktober 58 titik, November 8 titik dan Desember 9 titik.

2. Sebaran titik panas yang terdapat pada setiap kecamatan di Kabupaten Sintang tahun 2013 dan tahun 2014 secara berurutan adalah ; Ketungau hilir 205 titik, Ketungau Tengah 147, Ketungau hulu 123 titik, Tempunak 99 titik, Kayan Hilir 78 titik, Sepauk 75 titik, Binjai 58 titik, Kelam Permai 56 titik, Sungai Tebelian 49 titik, Ambalau 36 titik, Dedai 34 titik, Sintang 31 titik, Kayan Hulu 24 titik, dan Serawai 17 titik.

3. Sebaran titik panas yang terdapat pada status Kawasan Hutan Di Kabupaten Sintang Tahun 2013 dan tahun 2014 secara berurutan adalah ; Areal Penggunaan Lain (APL) 770 titik, Hutan Produksi (HP) 113 titik, 
Hutan Produksi Terbatas (HPT) 98 titik, Hutan Lindung (HL) 41 titik dan Hutan Produksi Konservasi (HPK), Taman Nasional (TN) dan Taman Wisata Alam (TWA) 10 titik.

4. Waktu yang rawan terjadi kebakaran hutan dan lahan adalah pada bulan Juli, Agustus dan September pada Kecamatan yang terdapat wilayah dengan status APL. Sedangkan sebagian besar penyebab kebakaran hutan dan lahan yang terjadi di Kabupaten Sintang, dilakukan oleh masyarakat yang melakukan pembersihan lahan dengan cara dibakar.

\section{DAFTAR PUSTAKA}

Anderson, et,al. 1999. Vegetatioan fires in Sumatera Indonesia : The Presentasion and Dristribution of NOAA-Derived Data. Palembang : Forest Fire Prevention and Control Project. European Union and Indonesia Ministry of Forestry and Estate Crops.

Departemen Kehutanan Republik Indonesia. 2007. Kebijakan Dalam Pengendalian Kebakaran Lahan dan Bencana Asap,
Makalah Seminar Lokakarya Pengendalian Kebakaran Lahan dan Hutan serta Penanggulangan Bencana Asap. Banjarmasin 30 Mei 2007.

Haeruman, H. 1980. Hutan Sebagai Lingkungan Hidup. Proyek Inventarisasi dan Evalusi Kualitas Lingkungan Hidup, PPLH, Jakarta.

Hawley, R.C. dan P.W. Stickel. 1948. Forest Protection. John Wiley And Sons, Inc. New York. Chapman and Hall, Limited. London.

Hidayat A., D.Kushardono, W.Asriningrum, A.Zubaedah I.Effendy, 2003. Laporan Verifikasi dan Validasi Mertode Pemantauan Mitigasi Bencana Kebakaran Hutan dan Kekeringan. Pusbang PTPJLAPAN.

Lembaga Antariksa dan Penerbangan Nasional. 2004. Kebakaran Hutan/Lahan dan Sebaran Asap di Sumatera dari Data Satelit Lingkungan dan Cuaca. Bidang Pemantauan Sumber Daya Alam dan Lingkungan Pusat Pengembangan Pemanfaatan dan Teknologi Penginderaan Jauh. Jakarta. 